\title{
Trade and the Spillovers of Transnational Terrorism
}

\author{
José de Sousa $^{a}$, Daniel Mirza and Thierry Verdier ${ }^{c}$
}

JEL-Classification: F12, F13

Keywords: terrorism, trade, security

\section{Introduction}

Terrorist organizations, like Al-Qaeda or the Taliban, have been recently extending their network beyond their original territory. As an example, Al-Qaeda recently extended its network in North Africa. This extension has not been limited to the Arab World, however. To gain visibility and logistical support, local groups in Non-Arab countries, e.g. in the Philippines or Uzbekistan, are increasingly being linked to the Al-Qaeda network (STEINBERG, 2008).

As terrorist activity is diffusing across borders, the authorities of targeted countries react by designing consistent security measures. For instance, the Homeland Security Bill voted in 2002 by the American congress will impose, by 2012, 100\% scanning of containers in foreign ports bound to the US. Other measures are more targeted against particular countries or regions. For instance, the nonimmigrant US visa issuance after $9 / 11$ reveals distortive measures of security. Some communities have been more affected than others (CAINKaR, 1999). ${ }^{1}$ The latest figures in US authorities' view tend to support the idea that, countries hosting terrorist organizations or their cells, should be watched more carefully. Security measures might thus create a distortion against these countries ending-up in less trade with the United States.

a Maison des Sciences Économiques, 106-112 boulevard de l'Hôpital, 75013 Paris; jdesousa@ univ-paris1.fr

b Faculté de droit et sciences économiques François Rabelais de Tours, 50 avenue Jean Portalis, 37000 Tours; daniel.mirza@univ-tours.fr.

c École normale supérieure, 48 boulevard Jourdan, 75014 Paris; verdier@pse.ens.fr.

1 On average, in 2002, Europeans experienced a 15\% decrease, Asians a 23\% decrease, and Muslim countries a $40 \%$ decrease with a large variance: from a tiny $1 \%$ drop for Eritrea to a $67 \%$ drop for Saudi Arabia. 
In this short paper, we try to assess the impact of terrorism cross-border diffusion on international trade. The facts suggest that the international mobility of terrorists leads to the expansion of security measures against potential host countries. To the extent that more stringent security policies lead to higher trade barriers, we investigate empirically the idea that countries close to the location of terrorism are experiencing lower trade.

Mirza and Verdier $(2006,2008)$ have already shown that trade is being affected by security policies set against countries of origin (i.e. countries of the first nationality of terrorists). In particular, they document that bilateral US imports are decreasing with the terrorist activity of the exporting country (MIRZA and Verdier, 2006). This short paper goes beyond their work. It represents a first attempt to consider security to have a more multilateral component: an increase in terrorism activity in one country drives an extended security policy towards the origin country of terror and its neighbor locations. Since security measures raise trade costs, terrorism sourced in one country should also exhibit negative spillovers on neighbor countries' trade.

We use a large data set of both US bilateral imports at the product level and terrorist incidents against the US over the period 1993-2002. We retain the United States as the targeted country for two reasons. First, it has been the main target of transnational terrorism in the last 40 years, being involved in nearly $45 \%$ of total terrorist incidents, and second it is associated with the largest variation across source countries of terrorism.

The empirical results tend to support the negative spillover effect of terrorism. We find that US bilateral imports are decreasing with the terror activity of both the exporting country and its contiguous neighbors.

The paper is structured as follows. In section 2, we present the data and the measure that we consider to identify the negative externality effect. In section 3 , we explain the empirical strategy. In section 4, we expose the benchmark econometric results and robustness checks. Finally, we conclude.

\section{Data on Trade and Transnational Terrorism}

Data on terrorist incidents come from the ITERATE dataset set-up by МicкоLUs et al. (2004) which reports transnational terrorist activities. ITERATE is an event-based dataset that provides information on the date, the country of localization of the attack, and the country of 1st nationality of terrorists and victims. It lists all of the incidents in the world that have been reported in the medias since 1968 onwards. We are mainly interested in those attacks where the US has 
been the main target, via its representative authorities, its army or its civilians anywhere in the world. ${ }^{2}$

Bilateral imports of the United States at the 4-digit SITC level, over the period 1993-2000, come from the NBER World Trade Data. The data report only values of flows that exceed $100,000 \$$ per year, however. This may induce a selection bias, since part of the exporters are developing countries that export little of many products and a very few set of particular products. To deal with this problem, we complete the NBER dataset with the French National Institute (INSEE) FLUBIL trade dataset, reporting flows below 1,000\$. FLUBIL is an updated version of the OECD bilateral trade data where some aggregation check-ups and minor corrections have been undertaken. It also completes the NBER dataset as it runs until 2002. Data on distance, contiguity and English common language come from the CEPII bilateral distance database (www.cepii.fr/anglaisgraph/bdd/ distances.htm). Data on population and GDP per capita come from the World Bank (World Development Indicators). The annual UN vote correlations data are based on the roll-call votes at the United Nations General Assembly. They come from the database created by Voeten and Merdzanovic ("United Nations General Assembly Voting Data”).

\section{Empirical Strategy}

\subsection{Distance to the Terrorist Organization}

We want to provide an empirical content to the concept of closeness to terrorism (or, symmetrically, distance from terrorism). We proceed in two steps. First, we determine how many 'close' neighbors a given country has. We consider that closeness is linked to sharing some cultural and geographical characteristics among countries. Such characteristics are simply and naturally related to contiguity. We thus argue here that countries are close neighbors when they share a border. For illustration, Table 1 presents a distribution of contiguous relationships among countries. At the top, it reports that 43 countries have no contiguous neighbors. They represent island countries and/or distinct statistical territories like French Reunion in the Indian Ocean. At the bottom, one country, namely China, has 14 contiguous neighbors. In between, Saudi Arabia for instance has in our data set six close neighbors, with whom it shares a border, i.e. Qatar, Kuwait, Jordan, Oman, United Arab Emirates and Yemen. 
Table 1: Distribution of Contiguous Relationships

\begin{tabular}{cc}
\hline Freq. of countries & \# of close neighbors \\
\hline 43 & 0 \\
18 & 1 \\
28 & 2 \\
25 & 3 \\
28 & 4 \\
20 & 5 \\
9 & 6 \\
7 & 7 \\
3 & 8 \\
3 & 9 \\
1 & 13 \\
1 & 14 \\
\hline
\end{tabular}

Second, we investigate the prediction that closeness to the origin country of terror is detrimental to trade with the US, by constructing a new variable, labeled neighbor incid. This variable sums the number of terrorist incidents against the US perpetrated by the 'closest' neighbor(s) of a given country. We capture thus the idea that increasing the proximity to countries perpetrating terrorist incidents increases the probability to host a terrorist cell. This variable is built for each year of our sample. We observe for instance that in 2002, the six closest neighbors of Saudi Arabia perpetrated 9 terrorists incidents against the US. We below incorporate this variable in our trade specification.

\subsection{Trade Specification}

To investigate empirically the negative spillover effect of terrorism, we use a simple gravity model of trade:

$$
\begin{aligned}
\ln \left(m_{j s t}\right) & =\alpha_{0}+\alpha_{1} \ln (N)_{j t}+\alpha_{2} \ln (Y / N)_{j t} \\
& +\alpha_{3} \ln (\text { dist })_{j}+\alpha_{4}(\text { lang })_{j}+\alpha_{5}(\text { contig })_{j} \\
& +\beta_{1}(\text { incid })_{j t}+\beta_{2}(\text { neighbor incid })_{j t}+\rho_{t}+\rho_{s},
\end{aligned}
$$


where $m_{j s t}$ is a $J \times 1$ vector with row $j$ equal to US imports from country $j$ in a given year $t$ for a given sector $s$. Our empirical strategy is worth commenting. First, we discard importing country-variable controls, such as the importer economic size and consumer price index, since in our data the importing country is always the US and these variables only have time-series variation. We capture such time-series variation by allowing for year specific effects in trade $\rho_{t}$. Second, we proxy the economic size of the exporting country by decomposing its gross domestic product $Y_{j}$ in population $N_{j}$ and GDP per capita $Y / N_{j}$, to control for size and development differences respectively. Third, we use disaggregate (sectoral) trade data to control for the relative specialization of countries which may be correlated both with aggregate trade and terrorism activities. We also allow for sector specific effects in trade $\rho_{s}$. Fourth, trade costs are proxied by some traditional observable factors: the distance of country $j$ to the US dist ${ }_{j}$ and two dummies contig $g_{j}$ and lang $_{j}$ indicating whether the US shares a border and/or a language with $j$. However, as described above, trade costs are also induced by the counter-terrorism measures implemented by the US government. Such measures are largely unobservable but positively correlated with the international terrorism activity. Consequently, we proxy the US security measures against country $j$ with the number of incidents the latter perpetrates against the US (incid). In addition, to investigate empirically the validity of our prediction, we incorporate into the Eq. 1 the neighbor incid variable, which sums the number of incidents of country $j$ 's closest neighbors against the US. Finally, in Eq. $1, \beta_{1}$ and $\beta_{2}$ are our coefficients of interest. They are expected to be both negative: an increase in the number of incidents, perpetrated by country $j$ or its neighbors, increases security measures (to prevent from potential future incidents), which leads to a decrease in US imports.

\section{Empirical Results}

\subsection{Benchmark Results}

In Table 2, we report results for Eq. (1). The specification includes a full set of year and sector specific dummies. Standard errors are clustered at the country $j$-year level to address potential problems of heteroskedasticity and autocorrelation in the error terms.

The traditional gravity estimates appear with the expected signs. An increase in exporter country per capita income and population promotes exports to the US with elasticities close to one as predicted by the theory of trade gravity. As 
expected, sharing the English language increases trade with the US. The estimate of contiguity reveals a much stronger effect (around 2) than in the literature (around 0.5 - see Disdier and Head, 2003). This could be due to the nature of our sample which considers the US as the sole importer. Thus, the estimate of contiguity captures the preferential North American Free Trade Agreement treatment as well as the impact of the unobservable affinities between the US and the adjacent countries. The elasticity of trade to distance is negative (around -0.2 ) but with a much lower estimate than in the literature (around -0.9 ). This is expected since once we control for contiguous exporters, the other exporters are quite far from the United States and differences in distance appear to be less detrimental to trade.

Table 2: Neighbor Incidents and Trade

\begin{tabular}{lc}
\hline Dependent variable & $\ln ($ US imports $)$ \\
\hline $\ln (\text { Population })_{j t}$ & $0.859^{\mathrm{a}}$ \\
& $(0.017)$ \\
$\ln \left(\mathrm{GDP} /\right.$ Pop $_{j t}$ & $0.850^{\mathrm{a}}$ \\
& $(0.014)$ \\
$\ln (\text { Distance })_{j}$ & $-0.205^{\mathrm{a}}$ \\
& $(0.048)$ \\
Contiguity $_{j}$ & $2.004^{\mathrm{a}}$ \\
& $(0.109)$ \\
English Language $_{j}$ & $0.325^{\mathrm{a}}$ \\
& $(0.045)$ \\
\# of Incidents ${ }_{j t}$ & $-0.010^{\mathrm{b}}$ \\
& $(0.005)$ \\
\# of Neighbor Incidents & $-0.005^{\mathrm{b}}$ \\
\hline Year Fixed Effects & $(0.002)$ \\
\hline Sector Fixed Effects (4-digit) & yes \\
\hline Adj. $R^{2}$ & yes \\
\# of Observations & 0.38 \\
\hline
\end{tabular}

Notes: heteroskedastic-robust standard errors in parentheses, clustered by country $j$ and year. a and b denote significance at the $1 \%$ and $5 \%$ level, respectively. Constant and fixed effects are not reported. 
We find a negative and significant effect of the terrorist incidents perpetrated by the exporting country $j$ against the US. On average, US bilateral imports decrease by about 1 percent for every additional bilateral terrorist incident against the US. Is this effect economically significant? To help with the interpretation of the results, we compute standardized (beta) coefficients from the estimates of Table (2). These are the regression coefficients obtained by standardizing all variables to have a mean of 0 and standard deviation of 1 . It follows that a one standarddeviation increase in the number terrorist incidents decreases US imports by .0097 standard deviation. In absolute value, this effect is much smaller than the standardized effect of the traditional gravity variables: .46 for population, .382 for GDP per capita, -.038 for distance, .127 for contiguity and .044 for common English language. Consequently, an additional terrorist incident leads to an economically significant effect but its occurrence is not widespread.

Theory predicts negative local spillovers on US imports, when close exporting country's neighbors hurt the US. Empirical results of Table 2 basically confirm this prediction. We find a negative semi-elasticity of trade to the number of incidents perpetrated by the exporting country's neighbors. On average exports to the US decrease by 0.5 percent for every additional terrorist incident perpetrated by country $j$ 's neighbors against the US.

\section{Robustness Checks}

This section is devoted to checking the robustness of the spillover effect of transnational terrorism. We first attempt to control for potential omitted characteristics of the exporting country. A solution to capture (time-independent) idiosyncrasies of the exporters would be to introduce into the regression country- $j$ dummies. However, our variables of incidents are country $j$-specific and form a linear combination of the country- $j$ dummies. Hence, introducing the incident variables and country- $j$ dummies would introduce perfect multicollinearity into the regressions. We alleviate this problem by adding in Eq. (1) a set of income group dummies, following the World Bank's definition: High Income OECD, High Income Others, Upper Middle Income, Lower Middle Income, and Low Income. We next try to account for the political connections between the US and country $j$. Controlling for 'affinities' with the US seems important since strong political connections may offset the negative spillovers of closeness to the terrorist organizations. To proxy the political links between the US and country $j$, we introduce in Eq. (1) the correlation between countries' positions during votes on resolutions in the General Assembly of the United Nations. This correlation is based on the roll-call votes and computed annually. 
Table 3: Neighbors Incidents and Trade (Additional Controls)

\begin{tabular}{lc}
\hline \multicolumn{2}{c}{ (I) Income group dummies $_{j}$} \\
\hline \# of incidents ${ }_{j t}$ & $-0.012^{\mathrm{b}}$ \\
& $(0.006)$ \\
\# of Neighbor Incidents ${ }_{j t}$ & $-0.005^{\mathrm{b}}$ \\
& $(0.002)$ \\
Adj. $R^{2}$ & 0.38 \\
\hline \multicolumn{2}{c}{ (II) United Nations votes correlation with the US (annual) } \\
\hline \# of Incidents ${ }_{j t}$ & $-0.008^{\mathrm{b}}$ \\
& $(0.004)$ \\
\hline \# of Neighbor Incidents ${ }_{j t}$ & $-0.005^{\mathrm{b}}$ \\
& $(0.002)$ \\
Adj. $R^{2}$ & 0.39 \\
\hline
\end{tabular}

Notes: Heteroskedastic-robust standard errors in parentheses, clustered by country $j$ and year. a and b denote significance at the $1 \%$ and $5 \%$ level respectively. Constant and fixed effects are not reported. All regressions are based on 324,383 observations.

Table 3 presents the robustness results of the income group dummies in row I and the UN votes correlation in row II. To save space, we only present the estimates of $\hat{\beta}_{1}$ and $\hat{\beta}_{2}$. The other estimates remained unchanged and can be asked for upon request. Concerning the number of neighbor incidents, results are not sensitive to the additional controls: we still find local negative spillovers related to the closeness of the terrorist incidents of the neighbors.

\section{Conclusion}

In this short paper, we have examined the impact of transnational terrorism diffusion on security and international trade. To counter the diffusion of transnational terrorism, governments implement comprehensive security measures. These measures are directed both against the source countries of terror and their neighbor countries where terrorism may diffuse. Since security measures raise trade costs, we empirically verify that the closer a country to a source of terrorism, the higher the negative spillovers on its trade. Further work is still needed, however. First, we need a theory to understand the interplay between security 
policy, diffusion of transnational terrorism and international trade. Second, we must check the robustness of the spillovers of transnational terrorism to alternative definitions of both neighboring relationships and incidents.

\section{References}

Cainkar, L. (2004), "The Impact of September 11 Attacks and the Aftermath on Arab and Muslim Communities in the United States", GSC Quarterly, 13.

de Sousa, J., D. Mirza, and T. Verdier (2009), "Trade and Terrorism: Does the Neighbor Hurt", Mimeo.

Disdier, A.C., and K. Head (2008), "The Puzzling Persistence of the Distance Effect on Bilateral Trade", Review of Economics and Statistics, 90(1), pp. 37-48.

Mickolus, E., T. Sandler, J. Murdock, and P. Flemming (2004), International Terrorism: Attributes of Terrorist Events, 1968-2003 (ITERATE 5), Dunn Loring, VA: Vinyard Software.

Mirza D., and T. Verdier (2006), "Are Lives Substitute to Livelihoods: Terrorism, Security and US Bilateral Imports", CEPR working paper 6173.

Mirza D., and T. Verdier (2008), "International Trade, Security and Transnational Terrorism: Theory and a Survey of Empirics", Journal of Comparative Economics, 26 (2), pp. 179-194.

Steinberg, G. (2008), “The Islamic Jihad Union”, SWP Comments paper series.

Voeten, Erik, and Adis Merdzanovic, "United Nations General Assembly Voting Data", http://hdl.handle.net/1902.1/12379, (object name UNF:3:Hpf6qOkDdzzvXF9m66yLTg==, accessed 2009).

\section{SUMMARY}

We examine the impact of transnational terrorism diffusion on security and international trade. To counter the diffusion of transnational terrorism, targeted governments implement security measures against countries where terror could potentially diffuse. Since security measures raise trade costs, we argue that countries, close enough to those from where terror originates, should experience negative spillovers on their trade. We find evidence for this hypothesis in our data. We show that the closer a country is to a source of terrorism, the higher the negative spillovers on its trade. 